\title{
Uncertainty of Thermographic Temperature Measurement of Electric Units Contained in Switchgear
}

Krzysztof Dziarski

Poznań University of Technology, Institute of Electric Power Engineering, Piotrowo 3A, 60-965 Poznań, Poland

Arkadiusz Hulewicz

Poznań University of Technology, Institute of Electrical Engineering and Industry Electronics, Piotrowo 3A, 60-965 Poznań, Poland

\begin{abstract}
The result of the works presented is the uncertainty budget of a thermographic temperature measurement taken through an IR window. The type B uncertainty determination method has been employed. Publication of European Accreditation EA-4/02 has been patterned. Conditions prevailing in course of the thermographic temperature measurement of low-voltage electric units contained in the switchgear were recreated as part of the works. The measurement system has been presented. Components of the infrared radiation reaching the camera lens in case when an IR window was used and when an IR window was not used have been discussed Uncertainties estimated for the measurement done with an IR window and without an IR window have been compared.
\end{abstract}

Słowa kluczowe: uncertainty budget, thermographic, electric devices, switchgear, Infrared Window, Infrared Radiation

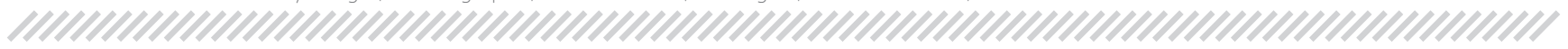

\section{Introduction}

It is possible to control the electric energy distribution in buildings by means of adequate electric devices. As the operating current flows through electric circuits of electric devices, their temperature increases. Temperature of electric devices may increase also as a result of the flow of overload and short-circuit currents through electric circuits. This happens in case of interferences [1, 2].

An excessive temperature increase may cause the electric devices to become damaged. When the electric circuit temperature exceeds the softening point, its structure changes irreversibly. In consequence, an excessively high temperature of an electric device current circuit may lead to its deformation and improper performance of the device [3].

Electric devices are connected by means of wires. In case of wires, one should make sure not to exceed the temperature above which their insulation gets deformed. It is a boundary temperature which depends on the material employed [4].

Autor korespondujący:

Krzysztof Dziarski, krzysztof.dziarski@put.poznan.pl

\section{Artykuł recenzowany nadesłany 06.08.2021 r., przyjęty do druku 21.10.2021 r.}

Knowing the temperature of electric devices and wires, one is able to answer the question: how much can one increase the operational current amperage not to cause damages?

If a wrong method is selected, it may be hazardous to carry out such a measurement. Improper measurement of temperature of electric devices by means of a temperature contact sensor may result in an electrocution of the person performing the measurement [5].

This risk can be prevented by means of another method, e.g. thermography. This contactless method is widely used to measure the temperature of electric devices, which has been proved by standards DIN-541912009-03, V2851 and V2859. One should remember that these are foreign standards and they can be used only as part of the good measurement practice [6-8].

Despite essential advantages, thermography also has drawbacks. It is an imprecise method. Additionally, the measurement result depends on a number of factors. The most important factors determining the value of the thermographic temperature measurement include has been described in [9].

IR windows are frequently used in the course of thermographic temperature measurements of electric devices contained inside a switchgear. These are inspection holes which make it possible to take a measurement without having to open the switchgear. While using cameras operating within the LWIR (Long Wave Infrared) limit, windows made of $\mathrm{CaF}_{2}$ are frequently used [10].

Such window can increase the safety of the person performing the measurement when used. Unfortunately, the thermographic temperature measurement taken with the use of an IR window is underrated. The measurement uncertainty also increases [11].

When reviewing literary sources, the authors did not find works devoted to the thermographic temperature measurement uncertainty budget with the use of an IR window. Neither did 
they find information about the difference between the expanded uncertainty of the thermographic temperature measurement done with the use of an IR window and the expanded uncertainty of the thermographic temperature measurement done without an IR window.

Therefore, research works were undertaken to determine the difference between the expanded uncertainty of the thermographic temperature measurement taken with the use of an IR window made of $\mathrm{z} \mathrm{CaF}_{2}$ and the expanded uncertainty of the thermographic temperature measurement taken without an IR window.

\section{Methodology}

\subsection{Measurement System}

The undertaken research works required a measurement system to be built. Its major part is an infrared radiator. It was designed so as to emit IR infrared radiation only in one direction.

It was an aluminium block sized $21 \mathrm{~cm} \times 21 \mathrm{~cm}$ coated with the Velvet Coating 811-21 paint with a known emissivity coefficient value $\varepsilon$ ranging from 0.970 to 0.975 for temperatures within the limit from $-36{ }^{\circ} \mathrm{C}$ to $82{ }^{\circ} \mathrm{C}$. The uncertainty with which the emissivity coefficient value was determined was 0.004 [12].

The control system employed made it possible to control the infrared radiator surface temperature. The radiator surface temperature was measured by means of the contact method

During the measurements, the radiator surface temperature was changed within a limit from $37^{\circ} \mathrm{C}$ to $70{ }^{\circ} \mathrm{C}$. The accepted lower limit of the limit was the design ambient temperature according to PN-HD 60364-5-52, arbitrarily increased so as to significantly differ from the ambient temperature. The acceptable temperature of the wire conductor in a polyvinyl chloride (PVC) [13] insulation has been considered to be the upper limit.

The radiator was placed inside a metal box sized $50 \mathrm{~cm} \times$ $50 \mathrm{~cm} \times 50 \mathrm{~cm}$. A $7.5 \mathrm{~cm}$ diameter hole was cut out in the front wall of the box. The VPFR-75 IR window was placed in the cut-out hole.

The Flir E50 thermographic camera (manufactured by Flir, Wilsonville, Oregon, USA) [14] was placed at a distance of $d=1 \mathrm{~m}$ away from the IR window.

In the further course of the works, information about air humidity and temperature inside the box and outside the box was important. The temperature and humidity sensor was used for this purpose. The measurement system designed is presented in this article (Fig. 1).

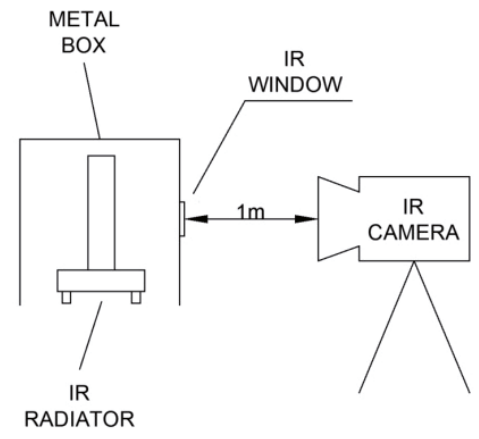

Fig. 1. Designed measurement station

Rys. 1. Skonstruowane stanowisko pomiarowe

\subsection{Measurement Equation}

The uncertainty of measurement is a non-negative parameter, associated with the result of a measurement that characterizes the dispersion of the values that could reasonably be attributed to the measurand [15].
The uncertainty can be determined by means of the Monte-Carlo method, type A method and type B method. Considering the small number of the completed measurements, it was decided to use the type B uncertainty determination.

This method is based on the analysis of results obtained from the completed measurements, calibration certificates and literature analyses. The use of the method is associated with designing the uncertainty budget.

In order to compare the uncertainty of the thermographic temperature measurement taken without an IR window and with an IR window, it is necessary to design two separate uncertainty budgets. For a case where an IR window effect on the thermographic temperature measurement result has not been taken into account and for a case where an IR window effect on the thermographic temperature measurement results has been taken into account. In both cases, the measurement equation will be different.

In a case where an IR window effect on the thermographic temperature measurement result is not taken into account, IR radiation emitted by the radiator, IR radiation reflected from the radiator and IR radiation emitted by the air layer situated between the radiator and the camera lens reaches the camera lens. In this case, the measurement equation takes the form (1) $[16]$.

$$
W_{t o t 1}=\varepsilon_{r} \cdot W_{o b j} \cdot \tau_{a}+\left(1-\varepsilon_{r}\right) \cdot W_{r e f f r}+\left(1-\tau_{a}\right) \cdot W_{a}
$$

where: $\varepsilon_{r}$ - radiator emissivity coefficient, $W_{\text {refr }}$ - radiation reflected from the radiator, $\tau_{a}$ - transmittance of the air layer between the radiator and the box, $W_{o b j}$ - radiation emitted by the radiator, $W_{a}$ - radiation emitted by the air situated between the radiator and the camera lens, $W_{\text {tot1 }}$ - total IR radiation reaching the IR camera lens where the IR window effect has not been taken into account.

Distribution of IR radiation reaching the IR camera lens is presented in this article (Fig. 2) and has been described in [17].

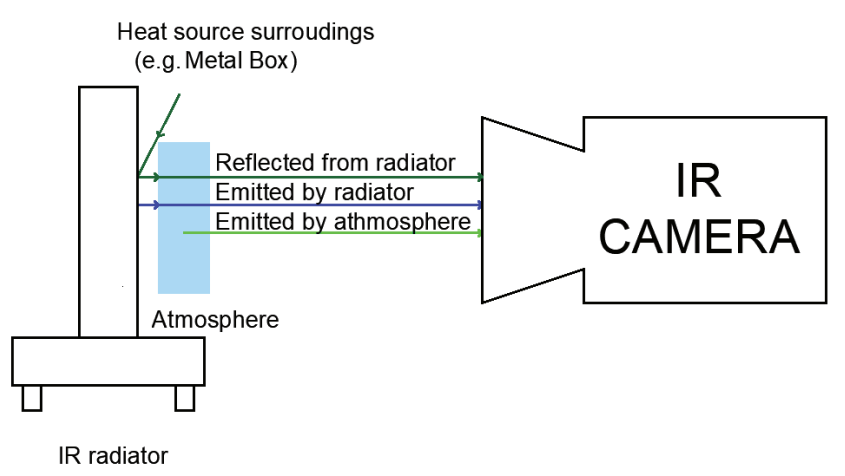

Fig. 2. Components of IR radiation reaching the IR camera lens, in case where the IR window is not included

Rys. 2. Składowe promieniowania IR docierającego do obiektywu kamery IR w przypadku, gdy nie uwzględniono okna IR

When the Stefan-Boltzmann law has been complied with and transformations have been performed, equation (1) takes the form (2):

$$
\vartheta_{o b j}=\sqrt[4]{\frac{W_{t o t 1}-\left(1-\varepsilon_{r}\right) \cdot \sigma \cdot \vartheta_{r e f l}^{4} \cdot \tau_{a}-\left(1-\tau_{a}\right) \cdot \sigma \cdot \vartheta_{a}^{4}}{\varepsilon_{r} \cdot \sigma \cdot \tau_{a}}}
$$

$\sigma$ - Boltzmann constant equal to $5.67 \mathrm{~cm} \times 10^{-8} \mathrm{~W} /\left(\mathrm{m}^{2} \cdot \mathrm{K}^{4}\right)$ Value $\tau_{a}$ can be determined by means of equations 9 and 10 . 
In case when an effect of the IR window made of $\mathrm{CaF}_{2}$ is taken into account, additional factors should be taken into account [11]. In this case, the IR radiation reaching the camera lens is a total of the radiation emitted by the radiator, radiation reflected from the infrared radiator, radiation emitted by the layer of air situated between the radiator and the box, radiation emitted by the lens, radiation reflected from the lens and radiation emitted by the layer of air situated between the IR window and the camera lens. Distribution of IR radiation reaching the IR camera lens is presented in this article (Fig. 3) and has been described in literature [18].

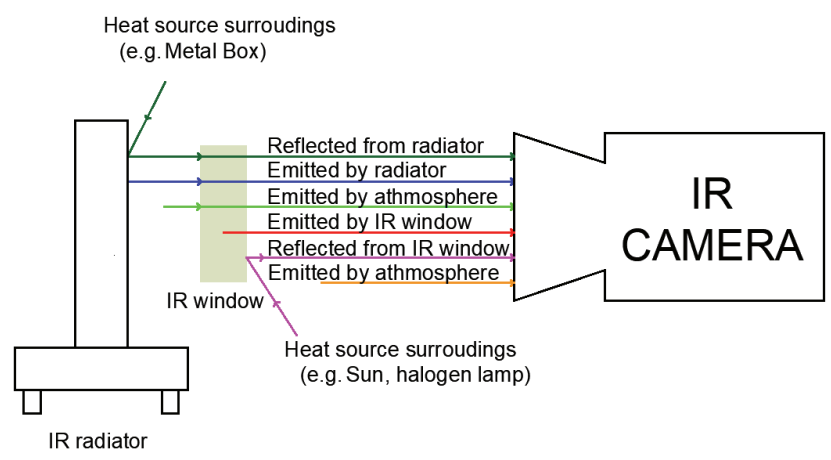

Fig. 3. Components of IR radiation reaching the IR camera lens, in case where the IR window is included, in case where the IR window is not included

Rys. 3. Składowe promieniowania IR docierającego do obiektywu kamery IR w przypadku, gdy uwzględniono okno IR

The total IR radiation reaching the camera lens $W_{\text {tot }}$ is described in equation (3).

$$
\begin{gathered}
W_{t o t 2}=\left(1-\varepsilon_{r}\right) \cdot W_{r e f t r} \cdot \tau_{a 1} \cdot \tau_{a 2} \cdot \tau_{w}+\varepsilon_{r} \cdot W_{o b j} \cdot \tau_{a 1} \cdot \tau_{a 2} \cdot \tau_{w}+ \\
+\left(1-\tau_{a 1}\right) \cdot W_{a m b 1} \cdot \tau_{a 2} \cdot \tau_{w}+\left(1-\tau_{w}\right) \cdot W_{w} \cdot \tau_{a 2}+\left(1-\tau_{a 2}\right) \\
\cdot W_{a m b 2}+\left(1-\varepsilon_{w}\right) \cdot W_{r e f l w}
\end{gathered}
$$

where: $\tau_{1}-$ transmittance of the air layer between the radiator and the box, $\tau_{2}$ - transmittance of the air layer between the box and the thermographic camera lens, $W_{a m b 1}$ - radiation of the air layer between the radiator and the box, $W_{w}$ - radiation emitted by the IR window, $\tau_{w}-$ IR window transmittance, $W_{a m b 2}$ - radiation of the air layer between the box and the thermographic camera lens, $\varepsilon_{w}$ - emissivity coefficient of the IR window, $W_{\text {reflw }}$ - radiation reflected from the IR window.

In order to reduce the number of variables in equation (3), the following simplifications (4-6) have been adopted:

$$
\begin{gathered}
\tau_{a 1}=\tau_{a 2}=\tau_{a} \\
W_{a m b 1}=W_{a m b 2}=W_{a} \\
\vartheta_{w}=\vartheta_{a}
\end{gathered}
$$

where: $\vartheta_{w}-$ IR window temperature, $\vartheta_{a}-$ ambient temperature.

With equations (4-6) and the Stefan-Boltzmann law being taken into account, equation (3) takes the form of equation (7):

$$
\begin{gathered}
W_{t o t 2}=\left(1-\varepsilon_{r}\right) \cdot \sigma \cdot \vartheta_{r e f f r}^{4} \cdot \tau_{a}^{2} \cdot \tau_{w}+\varepsilon_{r} \cdot \sigma \cdot \vartheta_{o b j}^{4} \cdot \tau_{a}^{2} \cdot \tau_{w}+ \\
+\left(1-\tau_{a}\right) \cdot \sigma \cdot \vartheta_{a}^{4} \cdot \tau_{a} \cdot \tau_{w}+\left(1-\tau_{w}\right) \cdot \sigma \cdot \vartheta_{a}^{4} \cdot \tau_{a}+ \\
+\left(1-\tau_{a}\right) \cdot \sigma \cdot \vartheta_{a}^{4} \cdot \tau_{a}+\left(1-\varepsilon_{w}\right) \cdot \sigma \cdot \vartheta_{r e f f w}^{4}
\end{gathered}
$$

where: $\vartheta_{\text {reftr }}$ - temperature reflected from the radiator, $\vartheta_{\text {reffw }}$ - temperature reflected from the IR window, $\vartheta_{o b j}$ - radiator temperature.

Finally, one can transform equation (7) to obtain equation (8) which makes it possible to calculate the radiator temperature base don the total radiation reaching the camera lens.

$$
\begin{gathered}
\vartheta_{o b j}=\sqrt[4]{\frac{A}{\varepsilon_{r} \cdot \sigma \cdot \tau_{a}^{2} \cdot \tau_{w}}} \\
A=W_{t o t 2}-\left(1-\varepsilon_{r}\right) \cdot \sigma \cdot \vartheta_{r e f t r}^{4} \cdot \tau_{a}^{2} \cdot \tau_{w}- \\
-\left(1-\tau_{a}\right) \cdot \sigma \cdot \vartheta_{a}^{4} \cdot \tau_{a} \cdot \tau_{w}-\left(1-\tau_{w}\right) \cdot \sigma \cdot \vartheta_{a}^{4} \cdot \tau_{a}- \\
-\left(1-\tau_{a}\right) \cdot \sigma \cdot \vartheta_{a}^{4}-\left(1-\varepsilon_{w}\right) \cdot \sigma \cdot \vartheta_{r e f l w}^{4}
\end{gathered}
$$

The value $\tau_{w}$ can be read from the manufacturer data and from the literary sources while the value $\tau_{a}$ can be determined by means of the formulas, which has been described in the literature $[19,20]$. In this case, the value of $d$ is smaller than $1.05 \mathrm{~m}$. During the analysis of the literature, it was noticed that for this value of $d$, the value of $\tau_{a}$ obtain on the basis of various models is close to 1 [19].

\subsection{Type B Evaluation of Uncertainty}

After the measurement equation is determined, the limit of variables provided on the right-hand side of equations (2) and (8) should be determined. These are input quantities. Then, an estimate of each input quantity $x_{i}$ should be determined by means of formula (9) [15].

$$
x_{i}=\frac{1}{2}\left(a_{+}+a_{-}\right)
$$

where $a_{+}$is the upper limit, $a_{-}$is the lower limit.

Then, equation (10) should be used to calculate standard uncertainty $u\left(x_{i}\right)$ of the input quantity [15].

$$
u^{2}\left(x_{i}\right)=\frac{1}{12}\left(a_{+}-a_{-}\right)^{2}
$$

The next step is to determine the sensitivity coefficient. Coefficient $c$ describes the effect of the changes in the value of input quantity estimate on the value of output quantity estimate. Coefficient $c$ can be calculated as a constituent derivative of the measurement function in relation to the input quantity [15].

There is also another way to determine the coefficient $c$ by means of numerical methods. For this purpose, one should calculate changes of the output quantity estimate caused by a change in the estimate $x_{i}$ of the input quantity by $+u\left(x_{i}\right)$ and $-u\left(x_{i}\right)$. The obtained difference in the output quantity estimate $y$ should be divided by $2 u\left(x_{i}\right)$. Contribution of uncertainty of the input quantity $u_{i}(y)=u\left(x_{i}\right) \cdot c$.

The standard uncertainty of the output quantity $u(y)$ is a square root of the sum of squares of uncertainty contributions (11) [21]. Quantities provided on the left-hand side of equation (8) should be understood as output quantities [22].

$$
u^{2}(y)=\sum_{i=1}^{N} u_{i}^{2}(y)
$$

Expanded uncertainty of the output quantity $U(y)$ is a product of $u(y)$ and the expansion coefficient $k$. Coverage factor is a number larger than one by which a combined standard measurement uncertainty is multiplied to obtain an expanded measurement uncertainty [15]. 
Taking into account the complexity of (2) and (8), it is necessary to design the value of the uncertainty budget $\vartheta_{o b j}$. This uncertainty budget should be designed taking into account the value $\vartheta_{a}$ from the literature and on the bases of the (8) $[23,24]$.

\section{Results}

\subsection{Determining Limit of Variables}

At the beginning, uniformity of the distribution of temperatures on the IR radiator was checked. The difference between the highest and the lowest temperature registered on the surface of the radiator was found to be $1.8^{\circ} \mathrm{C}[9]$.

Then, a box was put onto the radiator and the input value limit was determined for the radiator temperatures ranging from $37^{\circ} \mathrm{C}$ to $70{ }^{\circ} \mathrm{C}$. The temperature value was measured by means of the GM1365 Data Logger sensor. The reflected temperature was measured by putting wrinkled aluminium film alternately on the IR radiator and the IR window. During the reflected radiation measurement: preset $d=0$ and preset $\varepsilon_{r}=1$. The input data limits determined based on the measurements and literature [19] have been put in table 1 .

Tab. 1. Limits of the input data determined based on the IR radiator temperature measurements and literature within the limit from $37^{\circ} \mathrm{C}$ to $70{ }^{\circ} \mathrm{C}$

Tab. 1. Zakresy zmiennych wejściowych wyznaczonych na podstawie pomiarów i literatury dla temperatur promiennika IR z zakresu $37-70{ }^{\circ} \mathrm{C}$

\begin{tabular}{|c|c|c|c|c|}
\hline No. & Symbol & Unit & Upper Limit & Lower Limit \\
\hline 1 & $d$ & $\mathrm{~m}$ & 1.05 & 0.96 \\
\hline 2 & $\vartheta_{\text {reffr }}$ & ${ }^{\circ} \mathrm{C}$ & 38.1 & 29.6 \\
\hline 3 & $\vartheta_{a}$ & ${ }^{\circ} \mathrm{C}$ & 27.1 & 26.9 \\
\hline 4 & $\vartheta_{\text {reffw }}$ & ${ }^{\circ} \mathrm{C}$ & 35.2 & 28.1 \\
\hline
\end{tabular}

Limits $\varepsilon_{r}, \varepsilon_{w}, \tau_{w}, \tau_{a}$ were determined based on literary sources. Limits of these variables are presented in table 2.

At the end, for both cases (measurement with an IR window and without an IR window), limits $W_{\text {tot } 1}$ and $W_{\text {tot } 2}$ were determined. It was possible after inserting variable limits from tables 1 and 2 into equations (2) and (8). Equations $W_{\text {tot1 }}$ and $W_{\text {tot } 2}$ have been determined for every temperature of the IR radiator. The determined results are presented in table 3 .
Tab. 2. Limits of variables $\boldsymbol{\varepsilon}_{r}, \boldsymbol{\varepsilon}_{w}, \boldsymbol{\tau}_{w}$ and $\boldsymbol{\tau}_{a}$ determined based on literary sources

Tab. 2. Zakresy zmiennych $\varepsilon, \varepsilon, \tau$ oraz $\tau$ wyznaczone na podstawie literatury

\begin{tabular}{|c|c|c|c|c|}
\hline No. & Symbol & Unit & $\begin{array}{c}\text { Upper } \\
\text { Limit }\end{array}$ & $\begin{array}{c}\text { Lower } \\
\text { Limit }\end{array}$ \\
\hline 1 & $\varepsilon_{r}$ & - & 0.96 & 0.97 \\
\hline 2 & $\varepsilon_{w}$ & - & 0.62 & 0.25 \\
\hline 3 & $\tau_{w}$ & - & 0.5 & 0.4 \\
\hline 4 & $\tau_{a}$ & - & 1 & 0.6 \\
\hline
\end{tabular}

Tab. 3. Limits of variables $W_{t o t 1}$ and $W_{t o t 2}$ determined for all temperatures of the radiator

Tab. 3. Zakresy zmiennych $W_{\text {tot } 1}$ oraz $W_{\text {tot } 2}$ wyznaczone dla wszystkich temperatur promiennika

\begin{tabular}{|c|c|c|c|c|c|}
\hline \multirow{2}{*}{ No. } & \multirow{2}{*}{$\begin{array}{c}\text { Temperature of } \\
\text { the IR radiator }\end{array}$} & \multicolumn{2}{|c|}{ Upper Limit } & \multicolumn{2}{c|}{ Lower Limit } \\
\cline { 2 - 6 } & ${ }^{\circ} \mathbf{C}$ & $\mathbf{W} / \mathbf{m}$ & $\mathbf{W} / \mathbf{m}$ & $\mathbf{W} / \mathbf{m}$ & $\mathbf{W} / \mathbf{m}$ \\
\hline 1 & 37.7 & 0.11 & 0.11 & 0.11 & 0.09 \\
\hline 2 & 40.2 & 0.14 & 0.12 & 0.13 & 0.12 \\
\hline 3 & 53.2 & 0.44 & 0.27 & 0.44 & 0.22 \\
\hline 4 & 62.3 & 0.83 & 0.46 & 0.82 & 0.37 \\
\hline 5 & 72.3 & 1.50 & 0.80 & 1.50 & 0.64 \\
\hline
\end{tabular}

\subsection{Measurement Budget}

At the beginning, uncertainties for measurements in which no IR window was used were determined. The uncertainty budget for $\vartheta_{o b j}$ was designed. Estimates of input values $x_{i}$ were determined for the input values from equation (8) by means of formula (9).

Then, equation (10) was used to determine values of standard uncertainties $u\left(x_{i}\right)$ of input quantities. Values $c$ were determined numerically. The value $u\left(\vartheta_{o b}\right)$ was determined by means of formula (11). A separate budget was made for every preset of the radiator. An exemplary uncertainty budget for $\vartheta_{o b j}=53.2^{\circ} \mathrm{C}$ is presented in table 4 .

Tab. 4. Uncertainty budget for $\vartheta_{o b j}$ (measurement done while not using an IR window) $\vartheta_{o b j}=53.2{ }^{\circ} \mathrm{C}$ Tab. 4. Budżet niepewności dla $\vartheta_{o b j}$ (pomiar bez użycia okna transmisyjnego) $\vartheta_{o b j}=53.2^{\circ} \mathrm{C}$

\begin{tabular}{|c|c|c|c|c|c|}
\hline $\begin{array}{c}\text { Symbol } \\
X_{i}\end{array}$ & $\begin{array}{c}\text { Estimate } \\
\text { of quantity } \\
x_{i}\end{array}$ & $\begin{array}{c}\text { Standard } \\
\text { uncertainty } \\
u\left(x_{i}\right)\end{array}$ & $\begin{array}{c}\text { Distribution of } \\
\text { probability }\end{array}$ & $\begin{array}{c}\text { Sensitivity } \\
\text { coefficient } \\
\tau_{i}\end{array}$ & $\begin{array}{c}\text { Contribution of } \\
\text { uncertainty } \\
u_{\mathrm{i}}(y)\end{array}$ \\
\hline$\tau_{a}$ & $0.8-$ & $0.11-$ & normal & -12.53 & $-1.39^{\circ} \mathrm{C}$ \\
\hline$\varepsilon_{r}$ & $0.97-$ & $4.00 \cdot 10^{-3}-$ & rectangular & -11.40 & $-0.05^{\circ} \mathrm{C}$ \\
\hline$W_{t o t 1}$ & $0.44 \mathrm{~W} / \mathrm{m}$ & $2.60 \cdot 10^{-4} \mathrm{~W} / \mathrm{m}$ & rectangular & 30.21 & $7.85 \cdot 10^{-3}{ }^{\circ} \mathrm{C}$ \\
\hline$\vartheta_{r e f t}$ & $33.85^{\circ} \mathrm{C}$ & $2.45^{\circ} \mathrm{C}$ & rectangular & $7.39 \cdot 10^{-3}$ & $-0.02{ }^{\circ} \mathrm{C}$ \\
\hline$\vartheta_{a}$ & $27{ }^{\circ} \mathrm{C}$ & $0.06{ }^{\circ} \mathrm{C}$ & rectangular & $1.73 \cdot 10^{-3}$ & $1.00 \cdot 10^{-4}{ }^{\circ} \mathrm{C}$ \\
\hline$\vartheta_{o b j}$ & $53.2{ }^{\circ} \mathrm{C}$ & & & & $1.39{ }^{\circ} \mathrm{C}$ \\
\hline
\end{tabular}


Tab. 5. Uncertainty budget for $\vartheta_{\text {obj }}$ (measurement done while using an IR window) $\vartheta_{\text {obj }}=53.2{ }^{\circ} \mathrm{C}$

Tab. 5. Budżet niepewności dla $\vartheta_{\text {obj }}$ (pomiar z użyciem okna transmisyjnego) $\vartheta_{\text {obj }}=53.2^{\circ} \mathrm{C}$

\begin{tabular}{|c|c|c|c|c|c|}
\hline $\begin{array}{c}\text { Symbol } \\
X_{i}\end{array}$ & $\begin{array}{c}\text { Estimate } \\
\text { of quantity } \\
x_{i}\end{array}$ & $\begin{array}{c}\text { Standard } \\
\text { uncertainty } \\
u\left(x_{i}\right)\end{array}$ & $\begin{array}{c}\text { Distribution of } \\
\text { probability }\end{array}$ & $\begin{array}{c}\text { Sensitivity } \\
\text { coefficient } \\
c_{i}\end{array}$ & $\begin{array}{c}\text { Contribution of } \\
\text { uncertainty } \\
u_{\mathrm{i}}(y)\end{array}$ \\
\hline$\tau_{a}$ & $0.8-$ & $0.11-$ & normal & -25.18 & $-2.79{ }^{\circ} \mathrm{C}$ \\
\hline$\varepsilon_{r}$ & $0.97-$ & $4.00 \cdot 10^{-3}-$ & rectangular & -11.36 & $-0.05{ }^{\circ} \mathrm{C}$ \\
\hline$\tau_{w}$ & $0.45-$ & $0.03-$ & rectangular & -27.63 & $-0.80{ }^{\circ} \mathrm{C}$ \\
\hline$W_{\text {tot2 }}$ & $0.24 \mathrm{~W} / \mathrm{m}$ & $0.01 \mathrm{~W} / \mathrm{m}$ & rectangular & 68.42 & $0.98^{\circ} \mathrm{C}$ \\
\hline$\vartheta_{r e f t}$ & $33.85^{\circ} \mathrm{C}$ & $2.45^{\circ} \mathrm{C}$ & rectangular & $-7.38 \cdot 10^{-3}$ & $-0.02{ }^{\circ} \mathrm{C}$ \\
\hline$\tau_{a}$ & $27^{\circ} \mathrm{C}$ & $0.06{ }^{\circ} \mathrm{C}$ & rectangular & -0.17 & $-0.01{ }^{\circ} \mathrm{C}$ \\
\hline$\varepsilon_{r}$ & $0.44^{\circ} \mathrm{C}$ & $0.1^{\circ} \mathrm{C}$ & rectangular & 3.88 & $0.42{ }^{\circ} \mathrm{C}$ \\
\hline$\vartheta_{r e f w}$ & $31.65^{\circ} \mathrm{C}$ & $2.05^{\circ} \mathrm{C}$ & rectangular & -0.28 & $-0.57^{\circ} \mathrm{C}$ \\
\hline$\vartheta_{o b j}$ & $53.2^{\circ} \mathrm{C}$ & & & & $3.15^{\circ} \mathrm{C}$ \\
\hline
\end{tabular}

The value of the expended uncertainty $U\left(\vartheta_{o b j}\right)=5.58$ was obtained by multiplying the value $u\left(\vartheta_{o b j}\right)$ by $k=2$. A similar method was followed to design an uncertainty budget for the results of a measurement performed while using an IR window. The difference consisted in taking into account additional variables in the uncertainty budget for $\vartheta_{o b j}$, which was made based on equation (8). An exemplary uncertainty budget is presented in table 5 . In this case also $\vartheta_{o b j}=53.2{ }^{\circ} \mathrm{C}$.

Value $U\left(\vartheta_{o b j}\right)$ for $k=2$ increased to $6.3^{\circ} \mathrm{C}$. Table 6 presents the obtained uncertainty values $U\left(\vartheta_{o b j}\right)$ for $k=2$ for all temperatures of the radiator and both cases being analysed.

Tab. 6. Estimated uncertainties of thermographic temperature measurements taken with the use of an IR window and without it for all temperatures of the radiator

Tab. 6. Oszacowane niepewności termowizyjnych pomiarów temperatury z użyciem okna transmisyjnego oraz bez dla wszystkich temperatur promiennika

\begin{tabular}{|c|c|c|c|}
\hline \multirow{3}{*}{ No. } & \multirow[b]{2}{*}{$\begin{array}{l}\text { Temperature of } \\
\text { the IR radiator }\end{array}$} & \multicolumn{2}{|c|}{ Expanded uncertainty } \\
\hline & & $\begin{array}{c}\text { Measurement } \\
\text { without an IR } \\
\text { window }\end{array}$ & $\begin{array}{c}\text { Measurement } \\
\text { with an IR } \\
\text { window }\end{array}$ \\
\hline & ${ }^{\circ} \mathrm{C}$ & ${ }^{\circ} \mathrm{C}$ & ${ }^{\circ} \mathrm{C}$ \\
\hline 2 & 37.7 & 1.54 & 5.55 \\
\hline 3 & 40.2 & 1.76 & 5.17 \\
\hline 4 & 53.2 & 2.78 & 6.30 \\
\hline 5 & 62.3 & 3.43 & 7.36 \\
\hline 6 & 72.3 & 3.98 & 8.66 \\
\hline
\end{tabular}

\section{Conclusions}

As a result of the undertaken research works, uncertainties of thermographic temperature measurement of an infrared radiator without the use of an IR window and with an IT window have been estimated. An attempt was made to recreate conditions prevailing in course of the thermographic temperature measurements of electric devices contained in the switchgear.

The use of an IR window causes the measurement result to be underrated and the uncertainty to significantly increase. Additionally, the uncertainty increases as the temperature of the element under observation increases. The number of factors to be taken into account while designing the uncertainty budget increases, too.

Among the factors which have already been taken into account in case of a measurement without an IR window, the contribution of the ambient temperature and the total radiation reaching the thermographic camera lens.

Contributions of the factor associated with the radiator emissivity coefficient and the radiation reflected from the radiator remain the same. Additionally, the contribution associated with the radiation reflected from the radiator is negligibly small.

\section{References}

1. Tian W., Leit C., Jia R., Winter R.M., Probability Based Worn Circuit Breaker Modeling and Risk Evaluation on Potential Power Grid Failures, "IEEE 7th Annual International Conference on CYBER Technology in Automation, Control, and Intelligent Systems (CYBER)", 2017, DOI: 10.1109/CYBER.2017.8446423.

2. Książkiewicz A., Dombek G., Nowak K., Change in Electric Contact Resistance of Low-Voltage Relays Affected by Fault Current. "Materials". Vol. 12, No. 13, 2019,

DOI: $10.3390 / \mathrm{ma1} 2132166$.

3. Balabozov I., Experimental Research with Microcontroller System for Defining of Joule Integral of Fuse, $10^{\text {h }}$ Electrical Engineering Faculty Conference (BulEF), 2018, DOI: 10.1109/BULEF.2018.8646930.

4. Fangrat J., Kaczorek-Chrobak K., Papis B.K., Fire Behavior of Electrical Installations in Buildings. "Energies", Vol. 13, No. 23, 2020, 6433. DOI: 10.3390/en13236433.

5. Wesołowski M., Chmielak W., A new sensor system for measuring environmental parameters of switchgear, Progress in Applied Electrical Engineering (PAEE), 2017,

DOI: 10.1109/PAEE.2017.8009024.

6. [www.beuth.de/de/norm/din-54191/112450409] - DIN 54191:2009-03.

7. [www.beuth.de/de/technische-regel/vds-2851/337265955] VdS 2851:2021-02. 
8. [https://infostore.saiglobal.com/en-us/Standards/VDS-28592011-1117853 SAIG_VDS_VDS_2595666] - VdS 2859:2011.

9. Dziarski K., Hulewicz A., Determination of transmittance of $I R$ windows made of $\mathrm{CaF}_{2}$ within operational temperatures of electric devide, "Pomiary Automatyka Robotyka", R. 25, Nr 4, 2021, 25-30, DOI: 10.14313/PAR_242/25.

10. Madding R.P., IR Window Transmittance Temperature Dependence, [www.exiscan.com/images/files/TechNotes/Madding-IR window_Transmittance_Temperature_Dependance.pdf]

11. Holliday T., Kay J.A., Understanding infrared windows and their effects on infrared readings, Conference Record of 2013 Annual IEEE Pulp and Paper Industry Technical Conference (PPIC), 2013, 26-33, DOI: 10.1109/PPIC.2013.6656039.

12. Kawor E.T., Mattei S., Emissivity measurements for nexel velvet coating 811-21 between $-36{ }^{\circ} \mathrm{C}$ and $82{ }^{\circ} \mathrm{C}, 15$ ECTP Proceedings, 1999, DOI: 10.1068/htwu385.

13. PN-HD 60364-5-52:2011 - Instalacje elektryczne niskiego napięcia - Część 5-52: Dobór i montaż wyposażenia elektrycznego - Oprzewodowanie.

14. [www.thermokameras.com/Verkauf/Flir\%20e-Serie/Datenblatt\%20FLIR\%20E50\%20engl.pdf] - Technical Data FLIR E50.

15. European Co-Operation for Accreditation. [www.european-accreditation.org].

16. Tran Q.H., Han D., Kang C., Haldar A., Huh J., Effects of Ambient Temperature and Relative Humidity on Subsurface Defect Detection in Concrete Structures by Active Thermal Imaging. "Sensors", Vol. 17, No. 8, 2017, DOI: 10.3390/s17081718.
17. Minkina W., Pomiary termowizyjne - przyrzady i metody, Wydawnictwo Politechniki Częstochowskiej, Częstochowa 2004.

18. Minkina W., Dudzik S., Infrared Thermography Errors and Uncertainties; John Wiley \& Sons, Ltd.: Chichester, UK, 2009.

19. Minkina W., Klecha D., Atmospheric transmission coefficient modelling in the infrared for thermovision measurement, "Journal of Sensors and Sensor System", Vol. 5, 2016, 17-23, DOI: 10.5194/jsss-5-17-2016.

20. Więcek B., de Mey G., Termowizja w podczerwieni. Podstawy $i$ zastosowania, Wydawnictwo PAK, Warszawa 2011.

21. Morello R., GUM-Based Decisional Criteria to Make Decisions in Presence of Measurement Uncertainty. "IEEE Transactions on Instrumentation and Measurement", Vol. 69, No. 8, 2020, $5511-5522$.

22. JCGM 100 - Evaluation of measurement data-Guide to the expression of uncertainty measurement [www.bipm.org/documents/20126/2071204/JCGM_100_2008_E.pdf/cb0ef43fbaa5-11cf-3f85-4dcd86f77bd6]

23. Ohlsson K.E.A., Olofsson T., Quantitative infrared thermography imaging of the density of heat flow rate through a building element surface. "Applied Energy", Vol. 134, 2014, 499-505, DOI: 10.1016/j.apenergy.2014.08.058.

24. Kuwałek P., Otomański P., Wandachowicz K., Influence of the Phenomenon of Spectrum Leakage on the Evaluation Process of Metrological Properties of Power Quality Analyser. "Energies", Vol. 13, No. 20, 2020, DOI: 10.3390/en13205338.

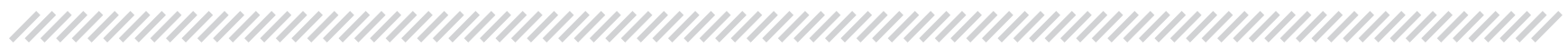

\section{Niepewność termowizyjnego pomiaru temperatury urządzeń elektrycznych umieszczonych w rozdzielnicy}

\author{
Streszczenie: Rezultatem zaprezentowanych prac jest budżet niepewności termowizyjnego \\ pomiaru temperatury wykonanego przez okno podczerwieni. Wykorzystana została metoda \\ wyznaczenia niepewności typu B. Wzorowano się na publikacji European Accreditation EA-4/02. \\ W ramach przeprowadzonych prac odtworzono warunki panujące w trakcie termowizyjnych pomiarów \\ urządzeń elektrycznych umieszczonych w rozdzielnicy. Zaprezentowano wykorzystany układ \\ pomiarowy. Omówione zostały składowe promieniowania podczerwonego w trakcie termowizyjnego \\ pomiaru temperatury w przypadku użycia okna inspekcyjnego oraz bez użycia okna inspekcyjnego. \\ Porównano oszacowaną niepewność pomiaru wykonanego z oknem inspekcyjnym oraz pomiaru \\ wykonanego bez okna inspekcyjnego.
}

Słowa kluczowe: budżet niepewności, termografia, urządzenia elektryczne, okno inspekcyjne, promieniowanie podczerwone

Krzysztof Dziarski, MSc Eng.

krzysztof.dziarski@put.poznan.pl

ORCID: 0000-0002-7877-4116

Assistant at the Institute of Electric Power Engineering, Poznań University of Technology. He attends the fourth year of doctoral studies. In 2017, having completed the second-cycle studies in the same field, he obtained a master's degree in engineering while defending the thesis entitled "Thermographic measurements of micronutrients". He specializes in issues related to temperature measurements, especially thermographic measurements.

\section{Arkadiusz Hulewicz, PhD Eng. arkadiusz.hulewicz@put.poznan.pl ORCID: 0000-0001-9342-7430}

A graduate of the Faculty of Electrical Engineering at the Poznań University of Technology, where he has been employed since 2001, currently as an assistant in the Department of Metrology of Electronics and Light Technology. Author and co-author of 80 publications. His main scientific interests are metrology, thermo-

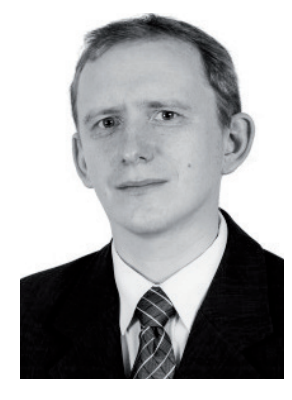
vision measurements, bio-measurements and biomedical engineering, optoelectronics, as well as modeling and signal processing. 